onversoenbaar met die Christelike antropologie en met die aard van die Kerk van Christus. Dus ook segregasie wat berus op wedersydse instemming? Dus ook segregasie soos dit in Gen. 10:32 en Deut. 32:8 vermeld word?

10. „Vryheid" is 'n woord wat dikwels gebruik word deesdae. Ken die kerk ook ander vryhede as die vryheid waarmee Christus hom vrygemaak het?

J. P. Oberholzer.

\title{
DIE KERK SE VISIE OP DIE RESENTE GEBEURE IN SUID-AFRIKA
}

Apartheid is geen ideologie nie. Dit is eenvoudig 'n beleid. Elke staat het 'n beleid ten opsigte van elke vraagstuk waarmee die land te doen het. So is daar 'n ekonomiese beleid, 'n buitelandse beleid, 'n binnelandse beleid en ten opsigte van die verskillende rasse in ons land, 'n rassebeleid. Waarom mense voortdurend probeer om so 'n rassebeleid te regverdig, of te veroordeel, op grond van uitsprake van Gods Woord, is vir my nog nooit duidelik nie. Waarom word dit nie gedoen met ons ekonomiese, binnelandse of buitelandse beleid nie? Gods Woord is tog nie 'n staatkundige, ekonomiese of volkekundige teksboek nie. Elke gelowige moet natuurlik ten opsigte van elke beleid waarvoor hy gevra word om te stem, homself verseker dat so 'n beleid nie 'n goddelose, onregverdige en anti-christelike beleid is nie. Alleen as 'n beleid nie indruis teen die Wet van God nie, soos Christus die Wet vir ons saamgevat het in die twee gebooie, naamlik dat jy God bo alles moet liefhê en jou naaste moet liefhê soos jouself, kan dit met 'n goeie gemoed ondersteun word. As ons rassebeleid dus sou indruis teen hierdie gebooie van God, mag ons dit nie ondersteun nie. As dit nie daarteen indruis nie, kan ons dit gewoon beoordeel op sy meriete, as 'n praktiese beleid. Omdat ons oortuig is dat apartheid nie teen Gods Wet indruis nie, wil ons apartheid as praktiese beleid beoordeel. Ons merk dan op dat daar ten opsigte van die rassevraagstuk drie denkrigtings is.

Daar is eerstens dié van volkome integrasie. Alle skeidlyne op grond van kleur of ras of beskawing moet uitgewis word. Hierdie denkrigting word in Suid-Afrika voorgestaan deur die Progressiewe Party, die Liberale Party sowel as verskillende meer of minder kommunisities-gekleurde organisasies en die Engelse Pers. Dit word ook voorgestaan deur die Engelse Kerke in ons land. Dit is ook die denkrigting van die buitelandse Pers, die Radio, politieke en ander organisasies. Sowel die kapitalisme as die kommunisme, die Weste as die Ooste onderskryf hierdie denkrigting. Ook die Christelike Kerk soos georganiseer in die Wêreldraad van Kerke, die Presbiteriaanse Alliansie sowel as die Kerke in lande soos Engeland, Holland, Amerika en Australië het in briewe aan ons Kerk hierdie denkrigting bepleit. 
Dat 'n oorhaastige toekenning van regte aan die Bantoe tot chaos lei, word bewys deur die gebeure in die Kongo. Die volk van Suid-Afrika sal so 'n beleid nooit aanvaar nie.

Daar is 'n tweede denkrigting wat meen dat gedeeltelike integrasie die oplossing bied. Dit is die denkrigting van die Verenigde Party. Hulle wil die Bantoe geleidelik stemreg toeken, maar so dat die beheer in Blanke hande bly. Van hierdie beleid kan ons alleen sê dat dit sowel oneerlik as onregverdig en kortsigtig is. Dit verloor dan ook geleidelik veld. As dit aanvaar sou word, sou dit presies lei waarheen volkome integrasie lei. Die verdwyning van die Blankes en die oorlewering van die Bantoe aan rhaos en die kommunisme, sal ook hieruit voortspruit.

Die derde denkrigting is dié van Apartheid. Die woord apartheid is deur 'n vyandige Engelse Pers aangegryp en met allerlei kwaaie bedoelings vereenselwig. Dit sou die uitdrukking wees van die Afrikaner se ,hertenvolk"-idee, wat in die swartes die minderes sien, wat deur hulle as diensknegte behandel kan word en wat geen menseregte het nie, of ooit kan kry nie. Niks is egter verder van die waarheid nie. Apartheid is juis die verwerping van rassediskriminasie. Dit is die erkenning van die Bantoe se reg om te bereik wat die Blankes bereik het. Dit aanvaar verder die feit dat in 'n gemengde gemeenskap so 'n ontplooiing vir die Bantoe onmoontlik sal wees. Daarom grond apartheid sy beleid van afsonderlike ontwikkeling op die historiese feit dat die deel van die Unie wat oorspronklik deur Bantoes bewoon is, hul tuisgebied sal wees, waar die Bantoe onbelemmerd deur Blankes, kan ontplooi. Dieselfde reg word aan die Blankes gegee in die gebied wat oorspronklik deur hulle bewoon is. Dit kom my altyd as uiters vreemd voor dat die Engelse in Engeland, die Hollanders in Holland, die Duitsers in Duitsland, die Amerikaners in Amerika, ens. vir hulleself die reg opeis om oor hul lotgevalle te besluit. Hulle sal baie verontwaardig wees as van hulle verwag word om hulle grense oop te gooi sodat Sjinese, Japanese, Indonesiërs en Jamaikaners in miljoene kan instroom, die regering oor te neem en hulle aansê dat hulle teenwoordigheid in Engeland, Holland, Duitsland en Amerika nie meer gewens is nie. Hulle sou onmiddellik in verset kom en sê dat dit hulle land is en dat hulle hul nie van vreemdes laat voorskryf nie. Aan ons ontsê hulle egter die reg. Hulle wil ons verplig om die miljoene Bantoes in ons land die stemreg te gee en so die regering aan hulle te oorhandig. Die Belgiese Kongo bewys wat van ons sal word. Hierdie vreemde houding van die buiteland berus op die feit dat hulle, óf uit onkunde óf uit moedswil, die historiese feit, dat 'n deel van SuidAfrika net so min aan die Bantoes behoort as wat dit aan Japan behoort, verontagsaam. Dit behoort aan ons Blankes. Juis hierdie historiese feit vorm die grondslag van apartheid. Samevattend kan ons dan sê dat apartheid die beleid is wat die Bantoetuistes wil ontwikkel sodat die Bantoes daar kan woon en uitgroei tot selfstandigheid en volwaardigheid, terwyl die Blankes onbedreig deur miljoene Bantoes dieselfde in hul 
gebied kan geniet. Nóg rassediskriminasie nóg onderdrukking of verontregting is daarom 'n deel van die apartheidsbeleid.

Teenstanders van die beleid kom gewoonlik met die volgende besware na vore: Eerstens beweer hulle dat die beleid onuitvoerbaar is omdat die Bantoetuistes nie in staat is om 'n lewensbestaan aan al die Bantoes te bied nie. Dit is van die bewerings wat net so moeilik is om te weerlê as om te bewys. As die Bantoetuistes net met boerdery ' $n$ lewensbestaan aan sy inwoners moet verskaf, kan mens aanneem dat dit nie kan nie. Maar watter land is daar vandag wat alleen uit boerdery bestaan? Lande wat so digbevolk is as Japan, Sjina, ens. bied tog 'n lewensbestaan aan sy miljoene as gevolg van industrialisasie. As ons die rykdom aan minerale waarmee Suid-Afrika geseën is in aanmerking neem, kan mens tog seker ook aanneem dat daar nog baie onontginde rykdomme in die bodem van die Bantoetuistes is wat nog op ontginning wag. Daar is dele van die wêreld waar 'n oppervlakte so groot soos die Bantoetuistes miljoene meer mense dra as die nege miljoen Bantoes. Dit is dus seker nie 'n uitgemaakte saak dat al die Bantoes nie in die Bantoetuistes kan bestaan nie. Daarby kom nog dat die regering met sy beleid van grensnywerhede beoog om werk te verskaf aan baie duisende van Bantoes wat binne die grense van hul eie tuisgebiede woon. Uiteindelik bly die feit nog staan dat in die Blanke gebied nog vir baie jare 'n tekort aan ongeskoolde en halfgeskoolde arbeiders sal bestaan sodat nog vir jare 'n paar miljoen Bantoes op die myne as tydelike arbeiders 'n lewensbestaan kan vind. Sulke tydelike of trekarbeiders is ook nie iets onbekends in die wêreld nie. As mens daarby nog bedenk wat alles met die geleidelike ontwikkeling van die Bantoes benodig word, soos byvoorbeeld dokters, aptekers, verpleegsters, advokate, prokureurs, ingenieurs, klerke, winkeliers, ambagsmanne, ens. dan kan mens bereken dat vir die Bantoe 'n goue eeu voor die deur staan. ' $n$ Tweede beswaar teen apartheid is dat daar nog geen vordering gemaak is nie en dat die voorstanders van apartheid nie erns maak met die uitvoering van die beleid nie. Hierdie beswaar is of kortsigtig of moedswillig. Die beswaarmakers is óf totaal onkundig oor wat aangaan of hulle verkleineer moedswillig wat gedoen is en wat gedoen word. Dit is tog billik om in aanmerking te neem wat die situasie was toe die huidige bewind met sy Apartheidsbeleid begin het.

Oor baie jare het Bantoes maar ingestroom na ons dorpe en stede. Met die toenemende industrialisasie van die land, het die instroming toegeneem. Veral gedurende die oorlogsjare en kort daarna was die instroming so geweldig dat chaotiese toestande rondom ons stede ontstaan het. Daar was geen woonvoorsiening vir die derduisende Bantoes gemaak wat ingestroom het nie. Plakkersdorpe het soos paddastoele rondom ons stede ontstaan. Hierdie plakkersdorpe het die broeiplek van boewebendes, skokiaanbrouers en misdadigers geword. Plekke soos Sophiatown, Cato Manor en ander het berugte plekke geword. Toe die huidige regering in 1948 aan bewind gekom het, was die toestand uiters haglik. Die regering het in 1948 tot 1953 oor so 'n klein meerder- 
heid beskik dat hy nie iets drasties kon anpak nie. Dit was eers vanaf 1953 toe sy meerderheid groot genoeg was om sterk te kan optree, dat daadwerklik opgetree kon word. Sedert hierdie tyd is die genoemde agterbuurtes met weinig uitsonderings opgeruim. Die duisende verspreide Bantoes rondom ons stede is saamgetrek in goedgeboude woonbuurtes soos Vlakfontein, Meadowlands en andere. Die opruimingswerk waarvoor die teenstanders van Apartheid nie kans gesien het nie, is nou so te sê voltooi. Gelyktydig is geweldige vordering gemaak met die verbetering van boerderybedrywighede in die Bantoetuistes. Die Bantoe-onderwyswet is aangeneem, waardeur die onderwys van die Bantoes oorgeneem is deur die regering en weggeneem uit die hande van die kerke wat dit voorheen as deel van hul sendingwerk behartig het. Die onderwys is veel beter aangepas by die behoeftes van die Bantoes en in nie meer op Europese lees geskoei nie. Universiteite is in die Bantoetuistes begin. Nou het die regering daartoe oorgegaan om Bantoeowerhede in te stel en 'n beleid van eie Bantoetuistes bekragtig en die beleid van grensnywerhede is aangekondig en sal kragdadig aangepak word.

Om dus te beweer dat min gedoen is, is eenvoudig onwaar. In die afgelope tien jaar is meer gedoen as in al die jare wat dit voorafgegaan het. Hierdie beswaar teen apartheid is dus van alle grond ontbloot.

'n Derde beswaar is dat apartheid ontvreemding van Bantoeregte beteken en dat onnodig veel leed veroorsaak word as gevolg van uittartende en onderdrukkende maatreëls soos die Groepsgebiedewet, die Ontugwet, Werksafbakening, die Paswette, ens. Wat hierdie wette betref, kan ons net die volgende sê:

Die Groepsgebiedewet bevat soveel beplannings wat bedoel is om verontregting uit te skakel dat die wet feitlik kragteloos is. Die Ontugwet belet bloedvermenging. Elkeen wat weet hoeveel ellende daar wag op kinders van gemengde bloed, sal hierdie wet verwelkom. Werksafbakening sal seker sommige personne benadeel. As dit egter nie daar is nie, sal duisende Blankes uit hul werk verdring word. Dus, of die wet daar is of nie, onreg sal aan baie gedoen word deur die feit dat Blank en Bantoe saamwerk en leef. Die paswette is natuurlik geen uitvindsel van apartheid nie. Dit is al deur die Engelse goewerneurs in die Kaap ingevoer. Al wat hierdie regering onder apartheid gedoen het, is om die pasdokumente saam te bind in een band sodat dit veel meer gerieflik sal wees. Dat hierdie pasboeke aangegryp is as 'n voorwendsel om vyandige demonstrasies te hou, is 'n baie deursigtelike voorwendsel. Die opstootjies was 'n lank vooruitbeplande aksie in die uitvoering van 'n plan om chaos te skep en die regering tot ' $n$ val te bring. Die gebeure by Langa en Sharpville volg dan ook die patroon van dergelike terroristebewegings in ander dele van Afrika.

Laastens moet ons nog aandag wy aan die historiese uitbarstings van die wêreldmening, met die Christelike Kerk op sleeptou. Hierdie oorgevoeligheid vir enige vorm van rassediskriminasie moet 'n oorsprong 
hê. Gedurende die vorige eeu was nóg die wêreldmening nóg die Christelike Kerk so fyngevoelig. Toe die "scramble for Africa" plaasgevind het, was die wêreldmening danig stil en ten minste een Kerk, naamlik die Anglikaanse Kerk, was selfs behulpsaam om die Britse Ryk uit te brei. Gedurende die afgelope wêreldoorlog, en ook kort voor die uitbreek daarvan, toe Hitler vyand nommer een was, het sy leer van die meerderwaardigheid van die Ariese ras en sy wrede vervolging van die Jode die demokratiese volke diep geskok. Die gevolg was die V.V.O. met sy verklaring oor menseregte. Alle mense, ongeag hul ras of kleur, besit gelykte regte. Hierdie verklaring is deur die gekleurde rasse aangegryp en as hefboom gebruik om hul eie onafhanklikheid te verkry. Dit is ook deur die kommunisme angegryp om as hefboom te gebruik om die Westerse Volke uit die Ooste en uit Afrika te dwing. Die Weste het hierteen vry magteloos gestaan. Hulle het die verklaring oor menseregt e so geesdriftig onderskryf en nou moes hulle die bewys lewer. Die gevolg was dat die Weste sy uiterste bes gedoen het en nog doen om die ko mmunisme te oorbie. So het die "Scramble out of Africa" dan begin en dit alles het gelei tot so 'n oorgevoeligheid vir die geringste sweem van rassediskriminasie. Agter alles sit natuurlik ook nog 'n groot mate van diplomasie. Daarom kry mens die snaakse verskynsel dat alleen diskriminasie teen swartes verontwaardiging uitlok. As Hollanders uit Indonesië uitgeskop word en alles moet verloor, of as Belge uit die Kongo moet vlug vir hul lewe, dan wek dit nêrens enige verontwaardiging nie. As Blanke polisie in Cato Manor op die wreedste en barbaarste wyse vermoor word is die wêreld doodstil, maar as die polisie op Bantoebetogers skiet, raak die wêreld histeries. Die verontwaardiging word dus aan en afgeskakel, soos dit vir die diplomasie dienstig is.

Wat die Christelike Kerk betref, word 'n houding geopenbaar wat baie bedenklik voorkom. Dat kommuniste, kapitaliste, Godloënaars en Mohammedane by geleentheid onder een kombers lê is nou nie juis ontstellend nie. Maar as die Christelike Kerk ook nog onder dieselfde kombers saam met die mengelmoes inkruip, word dit 'n enstige saak. Daar was seker nog nooit 'n tyd in die geskiedenis van die Kerk, waarin die Kerk so getrou die eggo van die wêreldstem was soos vandag nie.

Toe die V.V.O. sy deklarasie van menseregte uitreik, het die Kerk ook syne uitgereik. Natuurlik identies dieselfde, net in Bybelse taal. As die wêreld protesteer, protesteer die Kerk ook. As die wêreld swyg is die Kerk ook stil of spreek so sag dat dit op 'n tree-afstand onhoorbaar is.

Ons weet dan ook vooruit wanneer die wêreldpers begin raas oor iets wat in ons land gebeur, dan volg die briewe van vermaning en afkeur van die Kerke in die buiteland so seker as wat die dag op die nag volg. Hierdie byna slaafse navolging van die wêreldmening deur die Kerk laat my onwillekeurig dink aan 'n versietjie wat ons as kinders op skool geleer het: 


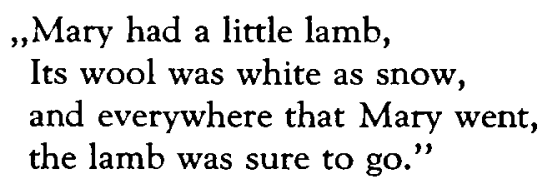

Wanneer die inboorlingvolke van Afrika, in die toekoms, óf weer teruggesak het in die donkere nag van primitiewe barbarisme, of versug onder die slawejuk van Moskou of Peking, sal dit eers blyk hoe groot die verraad was wat die paniekbevange Westerse volke teenoor Afrika gepleeg het. Die aandeel wat die Christelike Kerk gehad het in hierdie verraad sal seker nie ongestraf gelaat word nie. Hoe tragies is dit nie, dat die Kerk nie kan insien dat dit nou die tyd is vir die Kerk om 'n nugter, profetiese woord tot die wêreld te spreek nie. Dat aan die koloniale moondhede nou gesê moet word dat hulle, wat vir soveel jare vir Afrika gebruik het ter wille van sy rykdomme, ten minste die plig het om die primitiewe volke van Afrika, langsaam met 'n ferme hand te lei totdat hulle die peil bereik het waar hulle veilig en stewig op die pad van 'n ware, vrye onafhanklikheid, kan wandel.

Waar die Afrikanervolk en die Afrikaanse Kerk hierdie getuienis lewer, wil ons vertrou dat ons die nodige $\mathrm{krag}$ sal ontvang om nooit voor die wêreldmening te swig nie. Ons besef maar alte goed dat dit nie sonder 'n doel was dat ons in Suid-Afrika beland het nie. Ons geskiedenis lewer te veel bewyse van die leiding en bestuur van die Allerhoogste, in ons volksgroei. Danskraal en Bloedrivier, Paardekraal en Amajuba, Vereeniging en die totstandkoming van die Unie in 1910 tot die wonderbaarlike ontkoming aan die die dood deur ons Eerste Minister tydens die aanslag op sy lewe, mag vir baie toevalle wees. Ons glo dat dit die bestuur van die Allerhoogste is. Dat ons in aanraking met die primitiewe Bantoevolke gebring is, is ook geen toeval nie. Op ons rus die taak om hulle in hul eie gebiede te lei en op te voed tot volwaardige selfstandigheid. Dat dit 'n baie moeilike taak is, is seker. Dat ons deur die wêreld met die merkteken van Kain gebrandmerk word, dat ons volk en Kerk so luidkeels veroordeel en bedreig word, mag ons nie weerhou om in gehoorsaamheid aan God te volhard nie. Hierdie getuienis wil ons Kerk dan ook altyd teenoor owerheid en volk en die hele wêreld lewer.

A. J. G. Oosthuizen. 